\title{
SPESIES ASING SEBAGAI SALAH SATU PEMBATAS DALAM BUDIDAYA COPEPODA PADA BAK TERKONTROL
}

\author{
Media Fitri Isma Nugraha*) dan Gede S. Sumiarsa*) \\ *) Loka Riset Budidaya Ikan Hias Air Tawar \\ Jl. Perikanan No. 13, Pancoran Mas, Depok 16436 \\ Email: mfitri_isman@yahoo.com \\ **) Balai Besar Riset Perikanan Budidaya Laut \\ Jl. Br. Gondol, Kec. Gerokgak, Kab. Buleleng, Singaraja-Bali 81101
}

\begin{abstract}
ABSTRAK
Copepoda adalah golongan crustacean yang dapat dijadikan sebagai pakan alami untuk larva ikan. Secara umum copepo da tergolong dalam 4 ordo yaitu Calanoida, Cyclopoida, Harpacticoida, dan Monstrilidae. Di Balai Besar Riset Perikanan Budidaya Laut, Gondol, Copepoda yang dibudidayakan adalah jenis Harpacticoida yaitu Tisbe sp. yang pemeli haraannya dikerjakan dalam bak terkontrol. Copepod ini diberi pakan berupa phyto plankton, scoot's emulsion pellet ikan dan ragi serta sedikit penambahan probiotik. Pembatas selama budidaya adalah sulitnya produksi naupli copepoda secara massal, hal ini dikarenakan waktu bertelur yang tidak seragam antara individu copepoda, sehingga tidak bisa ditentukan waktu yang tepat untuk panen nauplii secara besarbesaran. Pembatas kedua adalah lambatnya reproduksi copepoda yaitu 14 hari jika dibandingkan dengan rotifer yang hanya 2 hari. Pembatas ketiga adalah adanya spesies asing atau predator yang menyerang copepoda pada kondisi tertentu, seperti tingginya nutrisi pakan pada bak pemeliharaan.
\end{abstract}

\section{KATAKUNCl: budidaya terkontrol, copepoda, spesies asing}

\section{PENDAHULUAN}

Copepoda di lautan bebas merupakan zooplankton dominant dari golongan crustaceae. Copepo da sebagai organisme multiselluer, memiliki jumlah spesies yang sangat besar yaitu sekitar 1.506 spesies, jumlah ini lebih banyak dari jumlah spesies serangga di daratan (Costello, 2000; Humes, 1994). Tidak semua jenis copepoda bisa dibudidayakan. Harpacticoida adalah salah satu jenis yang bisa dibudidayakan, karena copepoda jenis ini bersifat bentik dan memiliki adaptasi yang luas terhadap lingkungan. Semua copepoda memiliki pola perkembangan yang sama. Perkembangannya berawal dari telur yang ditetaskan, menjadi fase larva yang disebut naupli yang mempunyai 4 fase (N1-N4) kemudian berkembang menjadi copepodid yang terdiri dalam 6 fase (C1-C6), baru berkembang menjadi dewasa. Pada fase larva bentuk tubuhnya agak bulat dengan 3 pasang anggota badan, yaitu antene pertama, antenna kedua dan mandible (bagian bawah badan). Selama perkembangan larva naupli mulai memanjang, anggota badan mulai terlihat lebih panjang, jelas dan khusus. Copepoda juga mengalami metamorfosis pada fase naupli (N4) ke fase copepodid (C1). Morfologi copepodid lebih mendekati bentuk dewasa, dengan anggota badan jelas terbagi dalam prosom, urosome, dan rambut/duri pada ekor (Caudal rami) dengan jenis kelamin terpisah antara jantan dan betina (Williamson \& Reid, 2001).

Copepoda sangat cocok dijadikan pakan alami untuk larva ikan. Dibandingkan dengan rotifer dan artemia, copepoda memiliki banyak kelebihan antara lain mengandung asam lemak esensial EPA (eicosapentaenoic acid), docosahexaenoic acid (DHA), dan bahkan arachidonic acid (ARA) yang tinggi yang dibutuhkan dalam tahap awal perkembangan larva ikan (Watanabeet al., 1983; Witt et al., 1984). Selain itu, copepoda juga mampu meningkatkan kualitas warna pada ikan hias clown fish.

\section{Predator dalam Budidaya Copepoda}

Selain kelebihan tersebut diatas copepoda masih mempunyai masalah dalam budidayanya, dikarenakan lamanya siklus reproduksi di bandingkan dengan rotifer. Siklus reproduksi copepoda adalah 14 hari (dari naupli sampai menghasilkan naupli lagi). Tiga faktor lingkungan yang berpengaruh besar terhadap karakteristik kehidupan copepoda adalah suhu, kesediaan makanan dan predator.

Salah satu predator yang sangat ganas menyerang copepoda pada budidaya dalam bak di Balai Besar Riset Perikanan budidaya Laut, Gondol adalah spesies asing seperti Gambar 1. 


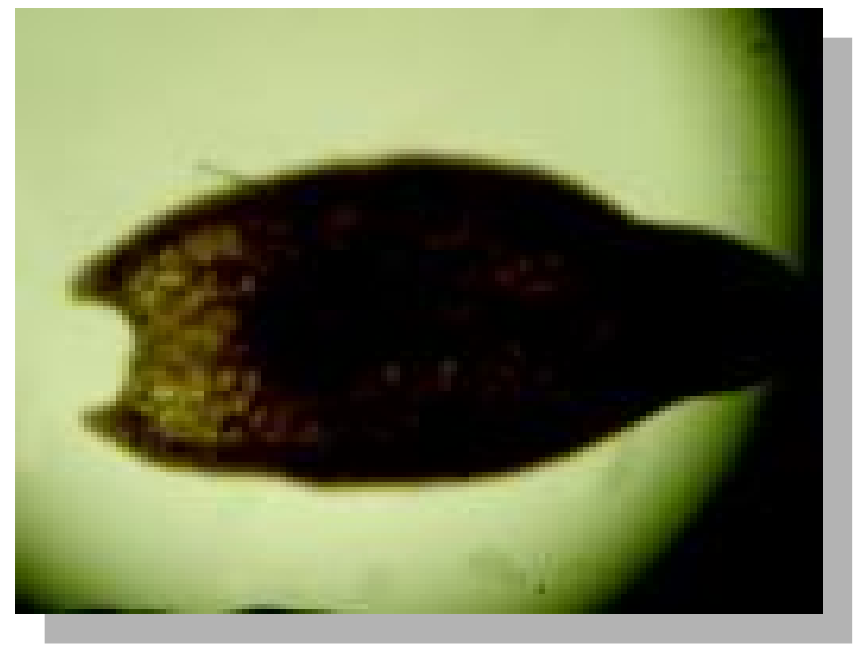

Gambar 1. Spesies asing yang menyerang copepoda pada bak terkontrol

Spesies ini belum diketahui jenisnya, akan tetapi diduga jenis plathyhelmintes atau Monogenea. Spesies ini muncul pada hari ke 16 setelah dilakukan pergantian air yang menyebabkan kematian secara besar-besaran pada copepoda, dan dapat berkembang dengan baik sampai menjadi banyak jumlahnya diduga karena banyaknya kandungan nutrisi dalam bak pemeliharaan. Dari pengamatan kelihatan yang terserang pertama kali adalah bak kultur yang diberikan tambahan probiotik.

\section{Dari Mana Asal Spesies Asing Tersebut?}

Predator ini diduga berasal dari air laut yang digunakan. Sebenarnya spesies ini dalam jumlah sedikit tidak berbahaya, akan tetapi dalam jumlah banyak tentu akan mengganggu. Spesies asing ini terdeteksi secara tidak sengaja pada saat pengamatan pada bulan September 2007.

Pengamatan September 2007 saat probiotik belum digunakan sebagai tambahan atau suplemen pakan, keberadaan spesies hampir tidak diketahui atau tidak kelihatan dikarenakan oleh kondisi lingkungan membuatnya tidak aktif (Oportunis Patogenik). Akan tetapi sesudah penambahan probiotik dan terjadi peningkatan nutrisi dalam bak kultur, sepertinya lingkungan menjadi cocok untuk spesies asing ini aktif dan berkembang, sehingga menyebabkan spesies asing ini berubah sifat menjadi patogenik. Dan tampak dengan jelas copepod dalam kurun waktu kurang dari 24 jam habis dan spesies asing berkembang dengan baik. Bakteri probiotik tampaknya menjadi biokontrol dari spesies asing ini. Berbagai mekanisme pertumbuhan misalnya dengan memproduksi senyawa penghambat ataupun dugaan terjadinya Quorum Sensing (komunikasi antar

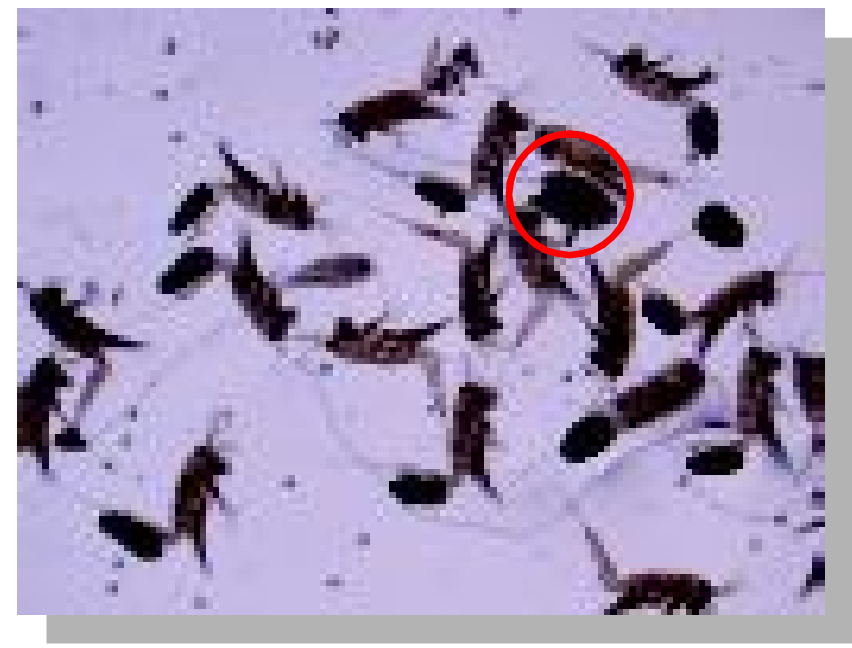

Gambar 2. Spesies asing (di dalam lingkaran merah) di antara copepoda saat kondisi tidak menguntungkan bagi spesies asing tersebut hanya terdapat 1 ekor dalam $50 \mathrm{~L}$ air laut

bakteri) yang merupakan model dari perkembang biakkan spesies ini.

\section{Cara Berkembang Biak Spesies Asing Ini}

\section{Mekanisme quaroum sensing}

Quaroum sensing adalah salah satu teknik komunikasi antar bakteri. Mekanisme kerja dari quaroum sensing adalah dari enzim luciferase dan substratnya berupa luciferin yang merupakan agent yang responsible untuk Bioluminescence. Bioluminescence adalah produk buangan yang diubah menjadi energi cahaya yang ada pada organisme hidup, dengan bahan utamanya adalah ATP (Adenin TriPhospat) (Anynomousc, 2009). Enzim ini terdapat pada semua hewan laut seperti bakteri, uburubur, dan hewan laut dalam. Serangga darat dan tumbuhan juga mengeluarkan bioluminescence ini (Hastings \& Morin, 1991). Luciferase menghasilkan cahaya dengan cara mengoksidasi luciferin yang bersifat ATP-dependent (Gambar 3). Reaksi enzim Luciferase berlangsung di dalam sel. (Anynomous, 2009d). Hal ini terbukti dengan cara mematikan copepod, dimana spesies asing ini menggumuli copepoda sehingga menjadi mati seketika. Kematian copepod ini diduga karena senyawa luciferase yang dikeluarkan oleh spesies asing tersebut.

Secara kimiawi bioluminescence mempunyai dua komponen utama, yaitu substrat (luciferin) dan enzim untuk mengkatalisis substrat yang mengeluarkan photon yang disebut luciferase. Pada organisme luminous (organisme dari phylum Echinodermata yang dapat mengeluarkan cahaya) tipe Luciferin diklasifikasikan dalam empat tipe yaitu (Coelenterata luciferin, Bacterial luciferin, 


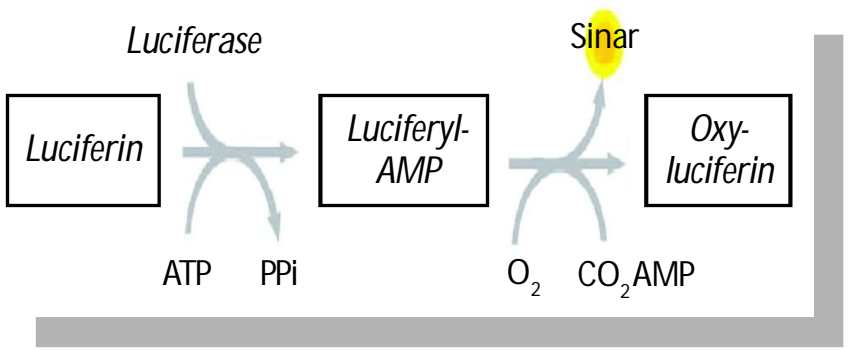

Gambar 3. Reaksi luminescence oleh luciferase

dinoflagellata luciferin, dan Firefly luciferin). Luminous pada bakteria terjadi dan dapat diamati pada semua bakteri yang hidup di air laut. Semua bacteri luciferases adalah heterodimeric dengan dua polypeptida alpha dan beta. Gen luciferase berasal dari sequence luminescent bakteri Vibrio, Xenorhabdus, dan bakteri dari genera Photobacterium (Szittner, 1990).

Pada bakteri expresi gen bioluminescece dikontrol oleh operon yang disebut "Operon Lux". Dua gen pengkode untuk dua sub unit bacteri luciferase masingmasing lux A dan lux B. Gen Luciferase terjadi karena adanya dua operon utama yang juga berasosiasi dengan protein lainnya dengan aktifitas luciferase meliputi sintesis aldehid. Operon ini juga mengandung gen untuk mengontrol perkembangan dan ekspresi dari luminescence oleh suatu mekanisme autoinduction (Nealson et al., 1970 dalam Narayanan, 2003). Operon luciferase mengandung 10 gen dan hanya merekam keberadaan dari autoinducer yang mana diproduksi oleh homoserinelactone oleh gen pemberi yang dalam operon diberi nama gen luxl. Autoinducer inilah yang merespon signal-signal dari sel dalam luminous bacteria, yang oleh Faqua et al. (1994) dalam Narayanan (2003) fenomena ini di sebut "Quarum sensing". Berikut proses pengiriman signal-signal dalam luminous bacteria.

Mekanisme bagaimana sel-sel dari bakteri berkomunikasi terlihat pada Gambar 5.

Jadi diduga kuat bahwa berkembangnya spesies asing ini adalah akibat dari mekanisme Quarum sensing yang

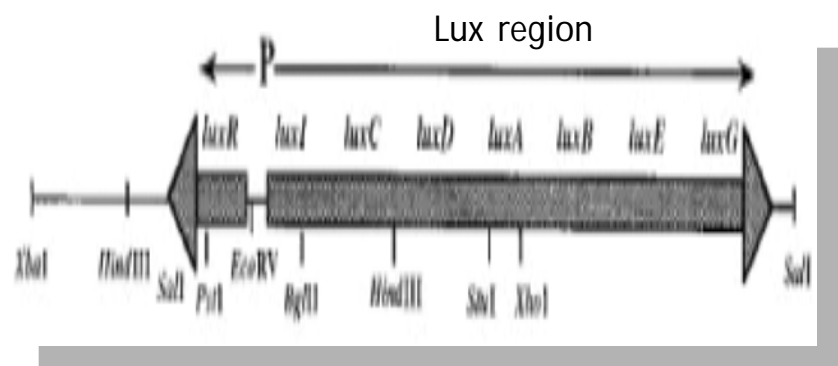

Gambar 4. Struktur gen Luciferase pada vibrio fischeri dan restriction site dimiliki oleh bakteri (bakteri probiotik + bakteri air laut) dan spesies asing (diduga dari phylum Echinodermata). Untuk bakteri nitirifikasi dan denitrifikasi bisa pula didefinisikan sebagai probiotik, karena kehadirannya mampu membuat tempat hidup ikan atau hewan budidaya lebih nyaman dan terbebas dari senyawa yang bersifat racun. Tetapi bakteri ini mungkin tidak bisa mengurangi patogen dan tidak berkontribusi langsung terhadap kesehatan ikan atau kesehatan hewan budidaya. Ini sering dipertanyakan sehingga bakteri nitirifikasi terkadang tidak dikategorikan dalam bakteri probiotik (Anonymousa, 2007).

Quorum sensing antar bakteri adalah bakteri dapat berkomunikasi satu sama lain dengan memanfaatkan molekul tertentu yang berperan sebagai sinyal. Dengan quorum sensing, populasi bakteri dapat meregulasi ekspresi gen dan pada akhirnya mempengaruhi komunitas bakteri tersebut (Henke \& assler, 2004 dalam http:// akuakultur.wordpress.com/2007/01/22/mekanismeantagonistik-dari-probiotik/). Peneliti dari lain membuktikan bahwa bakteri dapat menghambat quorum sensing dari bakteri pesaing dengan memproduksi enzim yang menonaktifkan molekul sinyal (Defoirdt et al., 2004 dalam http://akuakultur.wordpress.com/2007/01/22/ mekanisme-antagonistik-dari-probiotik/). Tampaknya pada pemakaian probitik pada kultur copepod ini bakteri proiotik yang digunakan merupakan bakteri nitrifikasi sehingga bakteri probiotik itu sendiri tidak dapat menghambat quorum sensing dari bakteri pesaing. Sehingga mengakibatkan tumbuh dan berkembang dengan subur spesies asing ini dan menyebabkan kerugian dalam budidaya copepoda.

\section{Persaingan dalam Kebutuhan akan Nutrisi}

Persaingan antara bakteri patogen dan copepoda dalam mendapatkan nutrisi dapat terjadi dalam kultur. Ketika dilakukan menambahkan probiotik pada air laut, harapannya adalah bahwa probiotik tersebut mampu menekan pertumbuhan bakteri patogen. Akan tetapi yang

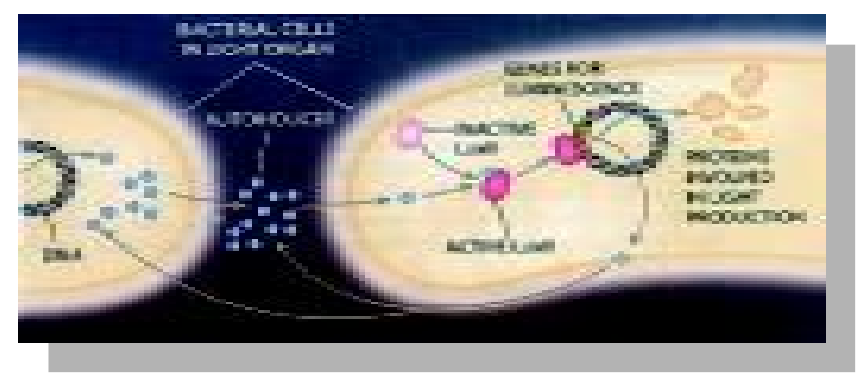

Gambar 5. Komunikasi antar sel-sel pada bakteri bioluminescent oleh autoinduction 
terjadi malah sebaliknya, memacu pertumbuhan predator lainnya. Dalam akuakultur probiotik didefinisikan sebagai penambahan mikroba hidup yang memiliki pengaruh yang menguntungkan bagi inang melalui modifikasi bentuk keterikatan (asosiasi) dengan inang atau komunitas mikroba lingkungan hidupnya. Probiotik digunakan dengan harapan dapat mengendalikan mikroba patogen tetapi juga memperbaiki kualitas air, akan tetapi pada kasus ini kondisi atau kualitas air dalam bak lah yang menyebabkan predator ini berkembang dengan baik.

Bacillus spp. merupakan kelompok mikroba yang sering digunakan sebagai probiotik terutama terkait dengan perbaikan kualitas air. Dari pemakaian probiotik terjadi perbaikan kualitas perairan dengan mengurangi konsentrasi senyawa kimia yang merugikan dan menyeimbangkan populasi mikroba dalam kolam atau tambak dengan menekan populasi bakteri patogen. Kehati-hatian terhadap potensi patogenik dan oportunis patogenik tetap di perlukan dalam memilih probiotik. Usaha preventif yang mungkin yaitu pemakaian jenisjenis mikroba yang telah dikategorikan sebagai GRAS (Generally Recognized As Safe) seperti saccharomyces cerevisiae dan Lactobacillus (Anonymous ${ }^{\mathrm{b}}$, 2007).

Berkembangnya spesies asing tersebut dapat pula dipicu oleh sukrosa yang tinggi. Kemungkinan spesies ini memanfaatkan sukrosa sebagai salah satu sumber energi untuk pertumbuhan dan perkembangannya. Jadi kondisi yang kaya akan sukrosa merupakan media yang sangat bagus bagi spesies ini untuk tumbuh dan berkembang. Spesies ini merupakan jenis plathyhelmites.
Plathyhelmites adalah organisme heterotrof yang tidak mampu menggunakan karbondioksida secara langsung, akan tetapi harus memperoleh karbon dari lingkungannya dalam bentuk molekul organik yang relatif kompleks seperti glukosa (Lehninger ${ }^{b}$, 1982). Glukosa terdiri atas beberapa komponen yaitu (selulosa, pati, fruktosa, manosa, sukrosa, dan laktosa). Spesies ini memanfaatkan sukrosa yang diurai oleh bakteri vibrio kuning. Sukrosa merupakan oligosakarida yang terdiri atas D-glukosa 6karbon dan $D$-fruktosa yang digabung dengan ikatan kovalen. Umumnya sukrosa dihasilkan oleh tumbuhan hijau seperti phytoplankton dan hewan tingkat rendah (bakteri) akan tetapi tidak terdapat pada hewan tingkat tinggi.

Berbeda dengan maltosa dan laktosa, sukrosa tidak mengandung atom karbon anomer bebas, karena karbon anomer kedua komponen unit monosakarida pada sukrosa berikatan satu dengan yang lain. Karena itulah sukrosa merupakan gula pereduksi yang hanya dihasilkan oleh proses fotosintesis dan hewan tingkat rendah seperti bakteri. Sukrosa merupakan teka-teki dalam biokimia. Hewan tidak dapat menyerap sukrosa secara langsung seperti tumbuhan hijau, akan tetapi dapat menyerap molekul tersebut dengan bantuan enzim suknosa, yang disebut sebagai invertase terdapat dalam sel yang membatasi dinding usus kecil. Enzim ini menkatalisa hidrolisis sukrosa menjadi D-glukosa dan Dfruktosa yang segera terserap dalam aliran darah (Lehningera ${ }^{a}$ 1982). Oleh karena itulah spesies asing yang diduga dari Phylum Plathyhelmites ini berkembang dengan subur dan bagus, yaitu dengan memanfaatkan sukrosa

Tabel 1. Perkembangan harian jumlah spesies asing/ml

\begin{tabular}{ccccccccccccccccccccccccccccc}
\hline \multirow{2}{*}{ Perlakuan } & & $\mathbf{1 1}$ & $\mathbf{2}$ & $\mathbf{3}$ & $\mathbf{4}$ & $\mathbf{5}$ & $\mathbf{6}$ & $\mathbf{7}$ & $\mathbf{8}$ & $\mathbf{9}$ & $\mathbf{1 0}$ & $\mathbf{1 1}$ & $\mathbf{1 2}$ & $\mathbf{1 3}$ & $\mathbf{1 4}$ & $\mathbf{1 5}$ & $\mathbf{1 6}$ & $\mathbf{1 7}$ & $\mathbf{1 8}$ & $\mathbf{1 9}$ & $\mathbf{2 0}$ & $\mathbf{2 1}$ & $\mathbf{2 2}$ & $\mathbf{2 3}$ & $\mathbf{2 4}$ & $\mathbf{2 5}$ & $\mathbf{2 6}$ & $\mathbf{2 7}$ \\
\hline $\mathrm{A} 1$ & 0 & 0 & 0 & 0 & 0 & 0 & 0 & 0 & 0 & 0 & 0 & 0 & 0 & 0 & 0 & 0 & 0 & 0 & 0 & 0 & 0 & 0 & 0 & 0 & 0 & 0 & 0 \\
$\mathrm{~A} 2$ & 0 & 0 & 0 & 0 & 0 & 0 & 0 & 0 & 0 & 0 & 0 & 0 & 0 & 0 & 0 & 0 & 0 & $\mathbf{2}$ & $\mathbf{2}$ & $\mathbf{1}$ & $\mathbf{1}$ & $\mathbf{1}$ & $\mathbf{4}$ & $\mathbf{2}$ & 0 & $\mathbf{1}$ & $\mathbf{2}$ \\
$\mathrm{A} 3$ & 0 & 0 & 0 & 0 & 0 & 0 & 0 & 0 & 0 & 0 & 0 & 0 & 0 & 0 & 0 & 0 & 0 & 0 & 0 & 0 & 0 & 0 & 0 & $\mathbf{2}$ & 0 & $\mathbf{1}$ & $\mathbf{7}$ \\
$\mathrm{B} 1$ & 0 & 0 & 0 & 0 & 0 & 0 & 0 & 0 & 0 & 0 & 0 & 0 & 0 & 0 & 0 & 0 & $\mathbf{6}$ & $\mathbf{3}$ & $\mathbf{3}$ & $\mathbf{2}$ & 0 & $\mathbf{3}$ & $\mathbf{3}$ & 0 & 0 & 0 & $\mathbf{7}$ \\
$\mathrm{B} 2$ & 0 & 0 & 0 & 0 & 0 & 0 & 0 & 0 & 0 & 0 & 0 & 0 & 0 & 0 & 0 & 0 & $\mathbf{6}$ & $\mathbf{4}$ & $\mathbf{2}$ & $\mathbf{2}$ & 0 & $\mathbf{7}$ & $\mathbf{5}$ & 0 & 0 & $\mathbf{1}$ & $\mathbf{4}$ \\
$\mathrm{B} 3$ & 0 & 0 & 0 & 0 & 0 & 0 & 0 & 0 & 0 & 0 & 0 & 0 & 0 & 0 & 0 & 0 & 0 & $\mathbf{5}$ & $\mathbf{5}$ & $\mathbf{4}$ & 0 & $\mathbf{2}$ & 0 & 0 & 0 & 0 & 0 \\
$\mathrm{C} 1$ & 0 & 0 & 0 & 0 & 0 & 0 & 0 & 0 & 0 & 0 & 0 & 0 & 0 & 0 & 0 & 0 & $\mathbf{8}$ & $\mathbf{4}$ & $\mathbf{4}$ & 0 & 0 & $\mathbf{1}$ & 0 & $\mathbf{1}$ & $\mathbf{1}$ & 0 & 0 \\
$\mathrm{C} 2$ & 0 & 0 & 0 & 0 & 0 & 0 & 0 & 0 & 0 & 0 & 0 & 0 & 0 & 0 & 0 & $\mathbf{4}$ & $\mathbf{1 0}$ & $\mathbf{4}$ & $\mathbf{4}$ & 0 & $\mathbf{2}$ & 0 & 0 & $\mathbf{5}$ & 0 & 0 & $\mathbf{1}$ \\
$\mathrm{C} 3$ & 0 & 0 & 0 & 0 & 0 & 0 & 0 & 0 & 0 & 0 & 0 & 0 & 0 & 0 & $\mathbf{6}$ & $\mathbf{4}$ & $\mathbf{1 0}$ & $\mathbf{6}$ & $\mathbf{2}$ & 0 & $\mathbf{4}$ & 0 & 0 & $\mathbf{1}$ & 0 & 0 & 0 \\
\hline
\end{tabular}

Keterangan :

A = Nanocloropsis oculata + Pelet + Scott's emulsion + Probiotik

$\mathrm{B}=$ Tetraselmis chuii + Pelet + Scott's emulsion + Probiotik

C $=$ Pelet + Scott's emulsion + probiotik

= Pertama kali spesies asing muncul

Bold $=$ Tempat dan jumlah spesies asing muncul 
sebagai sumber energi dengan bantuan enzim suknosa yang ada di dalam tubuhnya.

\section{KESIMPULAN}

Dalam budidaya atau kultur copepoda perlu juga di perhatikan keseimbangan antara mikroorganismenya. Pemakaian probiotik dalam akuakultur mempunyai dua dampak posistif dan negatif. Dampak positif dapat meningkatkan produksi, sedangkan dampak negatif akan menyebabkan kematian dan kerugian. Seperti halnya dengan munculnya spesies asing yang kebradaannya menyebabkan kematian bagi copepod, sehingga tujuan budidaya copepod tidak tercapai dan menyebabkan kerugian. Efisiensi penerapan probiotik dalam akuakultur akan sangat bergantung pada spesies dan strain bakteri probiotik itu sendiri (Anonymousa ${ }^{\mathrm{a}}$ 2007). Ketersediaan nutrisi yang cukup juga mempengaruhi tingkat produksi dalam budidaya.

\section{DAFTAR ACUAN}

Anonymous ${ }^{\text {a }}$ 2007. http://akuatika.net/?p=10\# more-10. Diakses tanggal 11 Desember 2007.

Anonymous $^{b}$. 2007. http://id.wikipedia.org/wiki/Probiotik. Diakses tanggal 28 November.

Anynomousc. 2009. http://en.wikipedia.org/wiki/Bioluminescence. Diakses tanggal 5 juli.

Anynomous ${ }^{d}$. 2009. (http://www.kamusilmiah.com/ biologi/mewarnai-dan-memendarkan-gen/).

Anynomous ${ }^{\text {. }}$ 2009. (http://akuakultur.wordpress.com/ 2007/01/22/mekanisme-antagonistik-dari-probiotik/).

Costello, M.J. 2000. A Framework for an action on marine biodiversiry in ireland. Prepared for the marine institute.
Hastings, J.W. \& Morin, J.G. 1991. Bioluminescence in neural and integrative animal physiology. Prosser.C.L. ed. Wiley-interscience. New York, p. 99-104.

Humes, A.G. 1994. How many copepods? Hydrobiologia, 292/293: 1-7.

Jose' Luis Balca' zar, Ignacio de Blas, Imanol Ruiz-Zarzuela, David Cunningham, Daniel Vendrell, Jose' Luis Mu'zquiz. Veterinary The Role of Probiotics in Aquaculture. Microbiology 114 (2006): 173- 186.

Leech, D.M., C.E. Williamson, R.E. Moeller, \& B.R. Hargreaves. 2005. Effects of ultraviolet radiation on the seasonal vertical distribution of zooplankton: a database analysis. Arch. Hydrobiol., 162: 445-464.

Liu, S.H., S. Sun, \& B.P. Han. 2003. Dial vertical migration of zooplankton following optimal food intake under predation. J. Plankton Res. 25: 1,069-1,077.

Narayanan, K. 2003. A review on Luciferase and its applications, p. 1-17.

Szittner, R. \& Meighen, E. 1990. Nucleotide sequence expression and properties of luciferase coded by lux genes from a teresterial bacterium. J. Biol. Chem., 265: 16,581-16,587.

Watanabe, T., C. Kitajima, \& S. Fujita. 1983. Nutritional values of live organisms used in Japan for mass propagation of fish: a review. Aquaculture, 34: 115-143.

Witt, U., G. Quantz, D. Kuhlmann, \& G. Kattner. 1984. Survival and growth of turbot larvae Scophthalmus maximus $L$. reared on different food organisms with special regard to long-chain polyunsaturated fatty acids. Aquacultural Engineering, 3: 177-190.

Williamson, C.E \& J.W. Reid. 2001. Copepoda ecology and classification of north American freshwater Invertebrates. $2^{\text {nd }}$ Edition. Academic Press. p. 915954. 